\title{
Do 'foreigners' pay more? The effects of investor type and nationality on office transaction prices in New York City
}

Article

Accepted Version

Devaney, S. and Scofield, D. (2017) Do 'foreigners' pay more? The effects of investor type and nationality on office transaction prices in New York City. Journal of Property Research, 34 (1). pp. 1-18. ISSN 1466-4453 doi: https://doi.org/10.1080/09599916.2017.1299197 Available at https://centaur.reading.ac.uk/70112/

It is advisable to refer to the publisher's version if you intend to cite from the work. See Guidance on citing.

To link to this article DOI: http://dx.doi.org/10.1080/09599916.2017.1299197

Publisher: Routledge

Publisher statement: The Version of Record of this manuscript has been published and is available in Journal of Property Research from 15/03/2017: http://www.tandfonline.com/doi/full/10.1080/09599916.2017.1299197

All outputs in CentAUR are protected by Intellectual Property Rights law, including copyright law. Copyright and IPR is retained by the creators or other copyright holders. Terms and conditions for use of this material are defined in the End User Agreement. 


\section{CentAUR}

Central Archive at the University of Reading

Reading's research outputs online 
Do 'foreigners' pay more? The effects of investor type and nationality on office transaction prices in New York City

\section{Steven Devaney ${ }^{1}$ and David Scofield ${ }^{2}$}

Contact author: Dr Steven Devaney

${ }^{1}$ Real Estate \& Planning, Henley Business School, University of Reading, Whiteknights, Reading, RG6 6UD, United Kingdom

E: s.devaney@reading.ac.uk

Dr David Scofield

${ }^{2}$ Real Estate Management, Ted Rogers School of Management, Ryerson University, 350

Victoria Street, Toronto, ON, M5B 2K3, Canada

E: dscofield@ryerson.ca

The Version of Record of this manuscript has been published and is available in Journal of Property Research from 15/03/2017:

http://www.tandfonline.com/doi/full/10.1080/09599916.2017.1299197

\section{Acknowledgments}

We thank Real Capital Analytics for access to data used in this research and we thank the participants at the 2016 International AREUEA meeting for helpful feedback and suggestions. We also thank the reviewers for their suggestions. Any errors are the responsibility of the authors alone. 


\title{
Do 'Foreigners' Pay More? The Effects of Investor Type and Nationality on Office Transaction Prices in New York City
}

\begin{abstract}
Are commercial real estate prices in metropolitan New York affected by the type or nationality of the investors involved in a transaction? Previous research has highlighted differences in pricing between in-state and out-of-state investors and between different types of investors, but there are few extant studies that consider the influence of nationality on pricing at a microlevel. Foreign investors might pay more than domestic investors for commercial real estate assets because of a lack of information or experience in the market concerned. However, they might use local partners or brokers to mitigate such problems. To explore these issues, we use data provided by Real Capital Analytics on over 3,000 office transactions in the New York metro area from 2001-2015. We use hedonic regression techniques and propensity score matching to examine whether pricing differs across investor groups after controlling for asset attributes. We find that foreign investors pay more than domestic investors at acquisition, but receive more when selling assets. Tests suggest that it is unmeasured aspects of quality that explain any apparent overpayment for offices in this location, not information issues.
\end{abstract}

Keywords: Commercial real estate, foreign investment, information asymmetry, pricing models, propensity score matching 


\section{Introduction}

It is well established that the physical and legal attributes of a commercial real estate asset, together with its location, affect the price that it can be sold for at any particular point in time. However, the role of investor characteristics such as organisation type or domicile in determining prices paid is far less understood. Such characteristics are likely to matter for pricing outcomes because of the private and decentralised nature of real estate markets in which trading is often characterised by bilateral bargaining between parties after extended search for appropriate assets (buyers) and counterparties (sellers). In this context, aspects such as information asymmetry, comparative bargaining strength, search costs, anchoring and costly reversibility have all been suggested in the literature as explanations for why premiums might be paid by certain groups of investors to acquire commercial real estate assets.

Some studies have explored differences between local and nonlocal (or out of state) investors in terms of pricing outcomes (Chinloy, Hardin, \& Wu, 2013; Ling, Naranjo, \& Petrova, 2013; Liu, Gallimore, \& Wiley, 2015). These studies identify distance as a key explanatory variable for price, especially in the case of purchasers. Distance contains a number of institutional, cultural and informational factors that can increase information asymmetry, search costs and other costs, potentially putting the non-local investor at a disadvantage (see McAllister and Nanda 2016a). However, the relationships between investor proximity and pricing might not be the same when it comes to domestic versus foreign investors, while evidence of a price premium for foreign investors would not necessarily provide proof of over-payment for assets because they may possess cost-of-capital advantages or be paying for added diversification benefits. 
This study examines whether or not the fact that an investor is 'foreign' affects transaction prices paid for commercial office buildings in New York City. New York is a hub of global capital and ranks top among US gateway cities in terms of absolute volume of foreign investment into commercial real estate (McAllister and Nanda 2015). This makes it a natural target for a study of foreign investment and pricing behaviour. To date, none of the studies of nonlocal investors and pricing has focused on New York City, though it has been included in some studies alongside other US metropolitan areas as part of a national sample. We believe that the unique status and importance of New York as a global financial centre and gateway city for foreign investment merits specific study of pricing behaviour within its commercial office market.

Interest in the behaviour and impact of foreign investors in commercial real estate markets has increased in the academic literature. Recently, Lieser and Groh (2014) and McAllister and Nanda (2016a) have analysed determinants of cross-border capital flows, while Mauck and Price (2015) have looked at the determinants of foreign ownership at the asset level. McAllister and Nanda $(2015,2016 b)$ tested whether an increased presence of foreign investors causes capitalization rates in a city to be lower, all else equal. To our knowledge, though, there has been little work on whether foreign investors either pay or sell for the same amounts as domestic investors in such locations when trading individual real estate investments. It is this gap in the literature that this study seeks to address.

We test whether foreign investors pay more than domestic investors when acquiring office buildings and whether they receive less when selling such assets after controlling for property, location and other investor factors. To do this, we use data for over 3,000 office transactions in the New York metro area over the period 2001-2015 as supplied by Real Capital Analytics 
(RCA). A hedonic regression framework is adopted using variables such as age and size along with variables that denote the type and nationality of the investors involved. However, results from probit models suggest that there might be systematic differences in the types of properties transacted by foreign investors, so we use propensity scoring to identify samples of domestic transactions involving buildings that are more comparable to those traded by foreign investors. This step not only makes the samples more like-for-like, but it also improves the regression diagnostics in the process.

The remainder of the paper proceeds as follows. First, literature concerning the impact of investor attributes on commercial real estate pricing is reviewed and we set our study within the context of this work. Next, we describe the data provided by RCA and the econometric methods that we use in our analysis. We then present and discuss the results before commenting on the relevance of our findings and making suggestions for future research.

\section{Existing literature}

A number of studies examine the role of buyer or seller attributes in explaining price premiums in real estate markets. The body of research in this area for commercial real estate is less than that for residential markets, but the number of such studies is growing. In our review, we briefly note some literature related to the effect of investor or organisation type on pricing before focusing our attention on issues connected with distance and nationality. To date, there has been only limited analysis of foreign investors in this literature. 
Colwell and Munneke (2006) studied the bargaining power of different types of commercial real estate investor by analyzing prices from 477 office deals in Chicago during 1995-97. The authors presumed that those acting on behalf of others (e.g. agents and third party managers) would pay more than those acting on their own behalf, and that different investor types would target different classes of office. Five buyer and seller categories were identified: Individuals, Individuals acting with Banks, Corporations, Corporations acting with Banks, and Banks acting alone; each buyer/seller was further defined based on whether that party had used a trust in the transaction. Corporations were found to have had more bargaining power (reflected in lower average prices paid) when compared to individuals acting with a bank and corporations acting with a bank. Furthermore, Individual \& Bank and Corporation \& Bank type investors selected a lower class of office than Corporations. Meanwhile, trusts were found to have had greater bargaining power than parties in non-trust transactions.

To explore links between performance outcomes and investor type, Wiley (2012) examines 633 office purchases, 448 sales and 99 paired transactions (corporate and non-institutional) occurring across 52 US cities during 2004-2011. He found a sharp disparity between corporate and non-institutional investors, with the former overpaying for assets by approximately $12 \%$ and underselling by around $10 \%$. He concludes that this may be due to the option values that investors apply when acquiring and selling real estate: that higher purchase prices equate to overvaluation of the put option for reversal, while lower purchase prices overvalue the call option. Wiley argues that interest cost is not likely to materially affect pricing by corporate investors given the presence of capital structuring options independent of the commercial real estate investment. However, in the context of foreign capital groups, and as predicted by the international capital asset pricing model, differences in access to global capital markets and potentially lower capital costs for foreign versus domestic investors might materially affect the 
pricing of commercial real estate.

Chegut, Eichholtz, and Rodrigues (2015) explored transaction prices of offices in six major cities over 2007-2013: Hong Kong, London, Los Angeles, New York, Paris and Tokyo. Their focus was on testing for spatial dependence in prices, but they included controls for buyer and seller type in their hedonic models. In the case of New York, their spatial dependence variables were statistically significant, but had little economic effect on prices. In regard to other variables, older and larger offices had lower prices per square foot, but taller buildings sold for higher prices per square foot. Meanwhile, with owner occupiers as the base group, equity funds, institutions and public companies such as REITs all paid more for New York offices, but did not sell for more, a pattern that was less apparent in other cities. Foreign buyers and foreign sellers were not defined or included with the other investor variables modelled.

A number of studies for residential real estate have sought to determine the effects of domicile on prices paid for real estate. Many have found evidence of overpayment by non-local investors. For example, Clauretie and Thistle (2007) examined 2,828 residential transactions in Las Vegas and found evidence of overpayment and price anchoring to home markets by outof-state buyers. Ihlanfeldt and Mayock (2012) analyzed 6,666 single family home sales in Florida and provide evidence supporting the 'distant buyer' hypothesis, noting overpayment and anchoring among 'inter-market' buyers when compared to transactions that involved local buyers. Providing an international perspective, Zhou, Gibler, and Zahirovic-Herbert (2015) studied pricing behavior among buyers of residential properties in Chengdu, China. They observed that buyers from outside the Chengdu area paid $1 \%$ more than locals on average, and that these buyers anchored price expectations to their home markets. 
For commercial real estate investments, Lambson, McQueen, and Slade (2004) questioned whether out-of-state buyers paid more and, if so, whether the premium was caused by anchoring of price expectations to home markets, information effects or (lack of) experience. Analyzing 2,854 apartment deals in Phoenix, Arizona (1990-2002), they found that out-of-state buyers paid more. Yet they found only limited anchoring and information effects on pricing, as well as some counterintuitive results regarding experience. Chinloy et al. (2013) examined 1,793 apartment transactions over a twelve year period in Atlanta, Georgia, and observed that prices were a product of both hedonic characteristics and investor attributes. They proxy for the effects of investor experience by using the number of transactions by each investor as a variable. Chinloy et al. found that nonlocal buyers and inexperienced local buyers received less of a discount when purchasing real estate compared to a subset of experienced local investors. Moreover, those investors who bought most frequently received greater price discounts. In contrast, a significant difference in sale receipts between local and non-local sellers was not found after controlling for other factors.

Fewer authors have studied office markets. Liu et al. (2015) studied office transactions in 138 US markets over the period 1996-2012 to test the effects of investor location (whether the buyer/seller was located in the same metropolitan area as the property) and anchoring bias on transaction prices. They concluded that non-local buyers were more likely to select newer, single tenanted Class A offices and pay significantly more for these than local investors acquiring similar assets, even after the use of propensity scoring to reduce observable differences in the samples. Premiums paid by non-local buyers were related to proximity, clientele and anchoring effects. The authors also found that non-local investors sold for significantly less than local investors when they came to dispose of assets. 
Eichholtz, Holtermans, and Yonder (2015) studied the US office sector, but focused on the interaction between distance and property management outcomes. They found that investors located closer to the buildings that they owned achieved better rental cash flows that those located further away, with the main driver for better income being stronger occupancy rates rather than higher rents. This might explain the results of Liu et al. (2015) in relation to distance and sale prices, as the stronger cash flows from locally-owned assets, holding other factors constant, should be more attractive to potential buyers. Eichholtz et al. also found that using external property managers helped distant owners to mitigate the disadvantage of distance for certain classes of office building. In a transaction context, we test whether the use of third-party brokers similarly helps to mitigate any negative pricing effects from investor domicile.

Finally, Ling et al. (2013) examined local and non-local pricing behavior with 114,588 office, industrial and apartment transactions for 15 US cities. They used a nautical distance of 50 miles from the property to define the nonlocal investor rather than in-state / out-of-state or metro / non-metro. They noted that for New York City, investors from New Jersey and Connecticut would be considered non-local/out of state in other studies, yet reside within 50 miles of New York and are unlikely to encounter greater information asymmetry compared to 'local' investors. Of course, an investor located 51 miles from an asset is unlikely to experience greater asymmetry than one 50 miles away, making this measure potentially problematic. Ling et al. concluded that, across the sectors and markets studied, distant buyers paid significantly more, but their findings for distant seller (selling for less) were not as strong. They also noted that the use of brokers was associated with increased purchase prices and lower sale prices, consistent with findings in the residential literature (e.g. Levitt and Syverson 2008). 
A key feature of distant investor studies is the assumption that information asymmetry is linked to distance, and that price premiums come with information asymmetry. However, there has been little work on whether similar issues exist in the case of foreign investors. ${ }^{1}$ McAllister and Nanda (2015) use MSA-level data for 38 US office markets to explore the impact of foreign investment on average capitalization rates. They also explore this for 28 European cities in a subsequent study (McAllister and Nanda, 2016b). To control for simultaneity bias, they isolate the element of each city's capitalization rate that is not explained by standard determinants such as risk free rates and rental growth proxies. They find that the presence of foreign investors is associated with lower capitalization rates and, so, higher prices. However, increased foreign investment equates to greater total numbers of investors crowding into fixed asset markets with limited, inelastic supply, so it could be this that puts greatest downward pressure on cap rates. The two studies do not test whether foreign investors pay more than domestic investors in those markets. It could be that both domestic and foreign investors pay more to acquire real estate in locations where more foreign investors are present.

Crosby, Jackson, and Orr (2016) analyse capitalization rates for 497 individual office transactions in Central London during 2010-2012. They control for physical, lease and submarket characteristics as well as buyer attributes. Buyer attributes included whether or not the buyer was domiciled in the UK, the broad world region from which the buyer originated and whether the buyer was international in scope or purely domestic. There were no corresponding variables for seller attributes. The authors found that capitalisation rates were negatively related to investment from continental Europe or the Middle East. They also found

\footnotetext{
${ }^{1}$ In the residential literature, some research in this vein is provided by Miller, Sklarz, and Ordway (1988), who examined Japanese investment into Honolulu housing markets, and Neo, Ong, and Tu (2008), who studied residential sales in Singapore over the period 1989-1999.
} 
that investors with purely domestic experience bought assets at higher capitalisation rates and, thus, lower prices. However, they acknowledge that such investors might not be competing for the same quality of assets, and that quality might not be fully captured in the controls that they use.

A fundamental issue is the separation of investors (buyers/sellers) into representative groups based on type (scope of activities and ownership) and location (domicile of beneficial interest). This exercise is often far from straightforward. McAllister and Nanda (2016a) have discussed how the presence of globalised investors with multiple headquarter locations and many capital sourcing possibilities complicates the process of identifying investor nationality. In their study of foreign ownership in the London office market, Lizieri, Reinert, and Baum (2011) caution that identifying beneficial interest and effective control can involve some investigation to distinguish the capital source and location of asset management. Despite noting problems with their approach, Lizieri et al. used the domicile and identity of the local managing agent as the location/domicile of the investment capital for private pooled real estate funds.

Problems of establishing identity and nationality are not confined to large global investors. Small private investors might seek the tax advantages and protections offered by particular corporate structures that, in turn, act to obscure their identity within available data. ${ }^{2}$ In the US, the Limited Liability Corporation (LLC) is a popular structure that shields the identity and

\footnotetext{
${ }^{2}$ Prior to reforms of the Foreign Investment in Real Property Tax Act (FIRPTA) enacted in December 2015, which exempt foreign pension funds from FIRPTA, foreign sellers of real estate were responsible for paying $10 \%$ (now 15\%) of the gross sales value of property sold to the Internal Revenue Service (IRS). However, LLCs with more than one beneficial owner (foreign or domestic) would avoid the withholding tax as they would be taxed as a US partnership and not a foreign entity.
} 
nationality of the beneficial investor. It provides personal liability protection and pass through tax benefits in a manner unique from other corporate structures (e.g. $\mathrm{C}$ and $\mathrm{S}$ corporations). LLCs can be run by third party managers and they can conduct interstate business, meaning that the location of the managing agent will not necessarily match the state in which the LLC is registered. For private foreign investors in US real estate, it is the only corporate structure available to them for this purpose and its use impacts the frequency with which foreign investment is recorded in real estate data, while rendering inaccurate some observations of investor distance used in previous studies.

McAllister and Nanda (2015) suggest that the use of domestic managers to manage capital pooled by multiple foreign investors is likely to be found in gateway markets with high value real estate assets such as New York. They also note that the local offices of global investment firms develop local human and social capital, and become embedded in local business networks, which challenges the concept of 'foreignness'. As a result, foreign investors in such locations might not experience significant information disadvantages and so will not pay a premium at acquisition or face a discount relative to local investors on the disposal of an asset. They might also acquire the market knowledge needed by using the services of third party brokers, in which case the penalty of distance would be borne through advisory fees rather than price effects.

Hence, although we postulate that foreign investors will pay more than domestic investors when acquiring offices in New York City, the debate in the literature around what constitutes a foreign investor means that we are not certain that a premium will emerge in the analysis. Meanwhile, we do not expect that foreign investors will sell their assets for less than local investors. This is because any effects from information asymmetry and anchoring should be 
reduced by experience gained through ownership in that market. In fact, for foreign and domestic buyers and sellers, we presume that experience will act to attenuate information asymmetry and this will be reflected in higher prices for sellers and lower prices for buyers. As a result, we try to control for experience levels in the analysis that follows.

\section{Data and methods}

The data used for this study are records of office sales in the New York metro area compiled by Real Capital Analytics (RCA) for the period 2001 to mid-2015. RCA tracks commercial real estate transactions above a threshold of $\$ 2.5$ million. Information on deals is obtained by RCA from multiple sources that include brokerage firms, investors, listing services, press reports and other public records. Data available on each deal includes some or all of the following: date of the transaction, price paid, size, age and number of floors for the property, address and location, and information on the buyers, sellers and brokers involved in the deal. Our specific interest is in the nature and nationality of the parties involved, but asset and location information is important for providing control variables that are likely to be significant determinants of the prices paid for different buildings.

Before conducting detailed analysis, we removed portfolio deals and properties/sites bought for redevelopment from our dataset. This left 3,908 office transactions for further analysis. We use this dataset to explore whether or not investor type or domicile has had any effect on transaction prices in this location. Issues surrounding the identification of nationality were noted above in our literature review. For this analysis, each buyer and seller in the dataset has been classified as either domestic or foreign based on the nationality attributed by RCA. If 
multiple parties were involved on one side of the transaction, e.g. as partners in a joint venture, then when at least one of the buyers or sellers was foreign, these transactions were grouped with the other foreign cases. However, another variable in our models allows for the effect on price of partnering with other investors to be examined. ${ }^{3}$

Another factor highlighted above is the use of LLCs by foreign real estate investors in New York and other US cities. In such cases, it is difficult to ascertain the true domicile of the investor involved, while to simply classify all LLCs as either domestic or foreign investors could distort the analysis. ${ }^{4}$ Hence, we omit cases where an LLC was named as the buyer or the seller from our samples. The impact that this has is shown in Table 1. LLCs were recorded as buyers in $21 \%$ of cases, as sellers in $14 \%$ of cases and as either buyer or seller in $30 \%$ of cases. Interestingly, their importance in terms of value is much more limited, with the value of transactions dropping from \$219 to \$207 billion when filtering on buyer and seller together. Although any fall in the samples is regrettable, we believe that it is better to filter out LLC deals and focus on the cases for which investor nationality is comparatively more certain.

\section{INSERT TABLE 1 HERE}

\footnotetext{
${ }^{3}$ The alternative treatment would be to classify such instances as domestic buyer or seller. However, since there were virtually no cases where all the joint venture partners were foreign, such treatment would have prevented the effect of joint ventures on prices from being tested owing to multicollinearity with the domestic / foreign indicator.

${ }^{4}$ The incidence of LLCs in this type of data is also noted by Chinloy et al. (2013). They use the address of the registered principals in their analysis, but we are not confident that this offers a reliable reflection of the source of capital for the cases in our dataset.
} 
Table 1 also reports the number of domestic and foreign transactions in the samples of deals that remain. In terms of number of deals, foreign investment is surprisingly rare, but its importance in terms of the value transacted is significant, with $42.5 \%$ of office deals by value involving a foreign investor. This suggests that the types of assets bought and sold by foreign investors differ from those that form the bulk of our sample, though lower value office buildings might be targeted by smaller foreign investors operating via the LLC route. The presence of such differences is tested formally below, but descriptive statistics in Table 2 provide further insights. This table reports arithmetic means for the dependent and some independent variables used in our modelling, disclosing how the means vary between domestic and foreign purchases and sales. Both continuous and dummy variables are reported. In the latter case, the means represent the frequency with which those attributes were observed in the sample.

\section{INSERT TABLE 2 HERE}

Table 2 shows that, as well as being more valuable, offices bought or sold by foreign investors were larger, taller and newer on average than those traded by domestic investors. A larger share of deals by foreign investors involved joint ventures or partial interests and a larger share were located in CBDs. Dummies for individual submarkets in the New York metro area were used in our models. Examination of the samples within these submarkets shows that a greater share of foreign investor activity was in downtown and midtown Manhattan, while domestic investor activity was spread more evenly. When selling offices, foreign investors were more likely to

use brokers, while, overall, brokerage was more prevalent on the sell side than the buy side of deals, consistent with Devaney and Scofield (2013). Finally, a higher fraction of foreign 
investors were institutions, a category that included insurance companies, pension funds, sovereign wealth funds and professionally managed investment funds.

The figures in Table 2 also suggest that foreign investors pay more per square foot for assets than their domestic counterparts. However, this does not mean that they are overpaying for properties because they might be selecting higher quality or better located assets and these attributes might lead to the differences observed. This appears to be supported by the fact that foreign investors received a higher price per square foot on average when they sold assets. It might also be that differences in experience are more important than nationality per se. Therefore, as in Chinloy et al. (2013), we sought to proxy the degree of experience by using the number of transactions that each investor had been involved in over the period. The analysis that follows uses a simple dummy that indicates whether an investor was involved in ten or more deals throughout the study period (as either a buyer or seller), but numerous alternative thresholds and versions of this variable were tested, yielding qualitatively similar results. ${ }^{5}$

To test our ideas further, econometric techniques that control for differences in the assets and the nature of each transaction must be used. Our starting point is a standard hedonic model whereby the log price per square foot in each case is explained using variables that capture the physical attributes and location of each asset. This framework is then augmented by the inclusion of investor related variables. We first estimate regressions using only information on

\footnotetext{
${ }^{5}$ The main limitation of this approach is that is cannot account for variations in experience over time. For example, a particular investor might be inexperienced in the New York market at the start of the period, but have gained experience by the end of the period as a result of trading and asset ownership. However, we cannot arbitrarily set 2001 as a baseline for the accumulation of market knowledge since some investors in the sample will be experienced already at that point.
} 
the buyers in each case and we then estimate similar regressions using only information on the sellers. This mirrors the approach of Liu et al. (2015) and enables larger samples to be modelled than if both buyer and seller information is needed. Nonetheless, we also model those transactions for which both buyer and seller information was captured. Thus, our three types of models are as follows:

$$
\begin{aligned}
& \operatorname{Ln}(\text { Price psf })=\alpha+\beta \mathrm{X}+\gamma \mathrm{B}+\delta \mathrm{L}+\tau \mathrm{T}+\varepsilon \\
& \operatorname{Ln}(\text { Price psf })=\alpha+\beta \mathrm{X}+\mu \mathrm{S}+\delta \mathrm{L}+\tau \mathrm{T}+\varepsilon \\
& \operatorname{Ln}(\text { Price psf })=\alpha+\beta \mathrm{X}+\gamma \mathrm{B}+\mu \mathrm{S}+\delta \mathrm{L}+\tau \mathrm{T}+\varepsilon
\end{aligned}
$$

Where X represents a set of asset attributes, B represents buyer characteristics, S represents seller characteristics, $\mathrm{L}$ represents submarket dummies and $\mathrm{T}$ represents time dummies, while $\beta, \gamma, \mu, \delta$ and $\tau$ represent the sets of parameters to be estimated in each case. However, as noted in Ling et al. (2013), it is possible that the parameters $\gamma$ and $\mu$ will capture several factors related to distance. One factor is the possibility of information asymmetry and differences in bargaining power, but another could be systematic differences in preferences for asset attributes that are not observed in the attributes represented by X. So, if foreign investors in this case transact higher quality assets than domestic investors and some of the dimensions of quality are not measured, then a positive coefficient on the foreign investor variable might occur even if no significant information or bargaining issues existed for such investors.

To distinguish between these effects, Ling et al. (2013) use a model in which dummy variables capturing relevant investor attributes (in their case, distance) are differenced from one another 
and also summed together. This relies on the assumptions that buyers and sellers would normally have symmetric bargaining power as well as symmetric demand for unobserved asset attributes (see Harding, Rosenthal, and Sirmans, 2003). Here, we have dummy variables for foreign buyers and foreign sellers that take the value of 1 if the investor concerned is foreign to the US and 0 otherwise. Denoting these variables as $\mathrm{B}^{\mathrm{F}}$ and $\mathrm{S}^{\mathrm{F}}$ respectively, they are combined as follows:

$$
\begin{aligned}
& B^{F}-S^{F} \\
& B^{F}+S^{F}
\end{aligned}
$$

In the former case, the resulting variable is positive where there is a foreign buyer and a domestic seller, negative where there is a domestic buyer and foreign seller, and zero otherwise. A positive coefficient on this variable would suggest that foreign investors are disadvantaged (pay more or receive less) relative to their domestic counterparts. In the second case, the variable takes a value of two where both parties are foreign, one if either buyer or seller is foreign, and zero otherwise. A positive coefficient here suggests that there are unobserved and positive price-related attributes associated with foreign investor transactions.

We not only use this technique to explore whether our findings for foreign investors are driven by information asymmetry or unmeasured quality, but we also use it to understand more about brokered transactions, joint venture transactions and our results for investor experience. Despite taking this approach, we recognise that further biases might arise if there are strong systematic differences in the nature of properties selected by foreign investors such that they constitute a distinct subset within the overall sample. Hence, as in the case of Liu et al. (2015), 
we estimate probit models to test whether the assets bought or sold by foreign investors can be predicted by the observable attributes of each building. We then estimate propensity scores based on these models and use these to create sub-samples in which the existence and scale of price differences between foreign and domestic investors are re-examined. The basic form of the probit models is as follows:

$$
\operatorname{Pr}\left[\mathrm{S}_{i}=1\right]=\Phi\left[\sum \gamma_{i} \mathrm{X}_{i}\right]+\varepsilon_{i}
$$

Where $\mathrm{S}_{i}$ equals 1 when the asset was traded by a foreign investor and 0 otherwise, while $\mathrm{X}_{i, t}$ are physical attributes used to predict that outcome and $\mathrm{T}_{t}$ are time dummy variables. Note that we omit investor dummies at this stage to focus on the inherent attributes of the assets concerned. ${ }^{6}$ The propensity score in each case then represents the probability of that purchase or sale having been undertaken by a foreign investor based on the observable factors.

These propensity scores were used in two different ways. First, each sample (for buyer, for seller and for combined models) was stratified into two halves using the median propensity score, and the regression was re-run using the half of the sample deemed most likely to be the subject of foreign investment activity. Second, the scores were used to match individual deals involving foreign investors with their closest counterpart among the domestic transactions. Matching was done on a 1:1 basis and with replacement such that a transaction in the domestic group could be used more than once as a match for a deal that involved foreign investors. As

\footnotetext{
${ }^{6} \mathrm{We}$ also have fewer submarket controls because some of the smaller and more distant submarkets from Manhattan have no or negligible foreign investment and thus predict the dependent variables in the probit models perfectly.
} 
Liu et al. (2015) note, this increases the accuracy of the matching, but makes it more difficult to find significant differences between the groups.

At each stage, standard regression diagnostic tests have been performed. These indicate that there is heteroscedasticity in the residuals from regressions using the full samples and stratified samples of observations. However, this is not always so for the regressions using the matched samples. Despite this, and as a precaution, we report levels of statistical significance based on heteroscedasticity consistent (or robust) standard errors in all cases. Variance inflation factors do not suggest any particular concerns regarding multicollinearity. The only variables with VIF scores greater than 10 are age and age squared following use of the latter to deal with the nonlinear relationship between price and age that commonly arises in hedonic pricing studies. If age squared is not included in the models, then the coefficients on variables other than age are largely unaffected.

\section{Results}

Table 3 provides the results from probit estimations. The results suggest that certain asset attributes are associated with the likelihood of an asset being traded by foreign investors. They confirm that foreign investors were more likely to buy or sell in Manhattan relative to other districts in the New York metro area. Foreign investors were also more likely to trade large assets. Age is a significant predictor for foreign investor purchases, but not sales. When buying, foreign investors were more likely to acquire newer office buildings. They were also more likely to trade condominium interests, but there is no significant positive coefficient for partial 
ownership stakes. ${ }^{7}$ Thus, our findings only match in part those of Mauck and Price (2015), who found a preference among foreign investors to own small stakes in large assets. Overall, there is evidence in Table 3 to suggest that there are differences in the properties traded by foreign investors, which motivates use of propensity scoring techniques to account for this.

\section{INSERT TABLE 3 HERE}

Table 4 presents results from regressions to explain pricing that use asset and buyer variables. The dependent variable in all cases is the logarithm of price per square foot for each transaction while year dummies were included in all models to control for the effect of general market movements on price. Results from a standard OLS regression are shown in the left hand column. These results are based on the largest possible sample of observations given the availability of data on the independent variables. In the middle and right hand columns, results are shown for regressions on stratified and matched samples as defined with reference to propensity scores. In this case, the propensity scores are derived from the probit model for foreign buyers shown in Table 3.

The models presented in Table 4 explain $60-63 \%$ of the variation in price per square foot in these samples. ${ }^{8}$ Coefficients for our asset variables are statistically significant in most cases and tend to have signs in line with expectations. Size exhibits a negative correspondence with

\footnotetext{
${ }^{7}$ Condominium interest refers to an ownership structure in which an individual (group, firm) owns a real estate unit(s) in a multi-unit development. In this structure, the owner has separate ownership of the unit(s) and an undivided interest in the common elements of the building.

${ }^{8}$ This is comparable with the models of New York office prices in Chegut et al. (2015), which captured $52-55 \%$ of the variation in their samples.
} 
price per square foot while taller buildings fetch higher prices per square foot, all else equal. The relationship between price per square foot and age is negative, but the coefficients are close to zero while the positive coefficient on the square of age indicates that this effect diminishes for older buildings. Buildings that were bought for renovation traded at lower prices per square foot, consistent with the need for buyers to undertake expenditure in order to update and improve the asset concerned. The submarket dummies, which are not reported in the table, also behave as expected, with offices in Midtown selling at a premium to those in Downtown (the base location) and offices in other areas tending to sell at a discount.

\section{INSERT TABLE 4 HERE}

Turning to the investor variables, there are many statistically significant coefficients in the case of the full sample, but not all effects persist when stratified and matched samples are analysed. The most persistent effects appear in the case of institutions and foreign buyers. Institutions, equity funds and publicly listed investors such as REITs pay a premium for office investments relative to the base group, private investors. This echoes results reported in Chegut et al. (2015). The premium paid by foreign buyers is $18 \%$ based on the model using all available observations, but it narrows to a (still significant) $9 \%$ in the matched sample. This raises the question as to what is driving this premium, which we address below.

When an acquisition was made by a joint venture, price per square foot was higher, all else equal, but this effect is neither statistically nor economically significant in the matched sample. The coefficient on the broker variable is negative in all cases, so when a broker was used by the buyer, price per square foot was lower, in contrast to the results of Ling et al. (2013). Once again, though, this result is not strong in all models, but is only statistically significant for the 
full sample. Finally, investor experience affects pricing, but the sign of the coefficient varies between models. We expected that experience would help reduce the prices being paid, but this is only apparent in the matched sample of transactions, and this might reflect the limitations in how this factor is measured.

Table 5 presents results of regressions that use asset and seller variables. These explain a similar amount of variation in log price per square foot to the models that use buyer variables. The results for the asset variables are very similar, so our discussion focuses upon the investor variables only. While other investor types bought at a premium to private investors, the results in Table 5 suggest that only publicly listed investors were able to sell at a premium. Joint ventures received higher prices per square foot when selling and experienced sellers also achieved higher prices per square foot. The latter finding is consistent with expectations. When a seller appoints a broker, higher prices per square foot appear to be achieved. Finally, foreign sellers achieve higher prices per square foot, all else equal. This is not consistent with our expectations; if foreign investors experience information disadvantages, then a price premium is expected at purchase, but not at sale.

\section{INSERT TABLE 5 HERE}

Table 6 presents the final set of results. The models reported here utilise asset, buyer and seller variables, and some of the key dummy indicators that represent buyer and seller characteristics are combined to form variables that test for the influence of asymmetry and unmeasured quality effects on the results, as discussed earlier. With both buyer and seller variables needing to be observed, sample sizes for the first two models are reduced versus their counterparts in Tables 4 and 5. However, the sample size for the matched sample is increased because the matching 
of domestic transactions is against assets that were either bought or sold by foreign investors. The use of both buyer and seller variables does not improve the explanatory power of the models to any significant extent, but the combined variables do yield additional insights.

\section{INSERT TABLE 6 HERE}

Once again, results for the asset variables are very similar to those discussed for Table 4 and so our discussion focuses on the investor variables. The dummies for investor type have coefficients that are consistent with earlier models and suggest that institutions and publicly listed investors buy at a premium, while only the latter sell at a premium. The bottom part of the table then contains results from asymmetry and unmeasured quality tests. In the asymmetry tests, a positive (negative) coefficient indicates that buyers of a specified type pay a premium (receive a discount) that is not matched by what sellers of that same type receive on exit. The only significant results from these tests relates to use of brokers. In two out of the three models, there is a significant and negative relationship between brokerage and prices, suggesting that those parties who used brokers were at an advantage when the counterparty was not similarly represented.

Meanwhile, results from the unmeasured quality tests are much stronger overall. Here, a positive (negative) coefficient suggests that buyers and sellers of a specified type are associated with higher (lower) prices per square foot. Foreign investors, experienced investors and joint ventures all have positive and significant coefficients in these tests, in the order of a $5-15 \%$ effect on price, all else equal. This suggests that foreign investors target assets that are higher quality not only in terms of the measured dimensions available in this dataset, but also in terms of unmeasured attributes that might include aspects such as tenant quality, leases and condition. 
Furthermore, experience matters, but not in ways that we assume. The results suggest that our proxy for investor experience, which is shared by earlier studies, is too correlated with investor scale, with larger investors better able to bid for high quality assets than less experienced and smaller counterparts.

Thus far, the effects of time have been controlled for using year fixed effects. Yet it is possible that the other coefficients are not stable over time owing to the different market conditions that the study period spans. Therefore, to check the robustness of the findings, all models were reestimated for two sub-periods: 2001-07, associated with rising prices, and 2008-15, covering a pronounced downturn and subsequent recovery. Selected results from this exercise are reported in Table 7. Panel A reports the coefficients for the foreign investor variables and for variables that capture ways to overcome information problems, namely experience, use of a broker and use of a partner as captured by the joint venture indicator. Panel B reports coefficients from the asymmetry and unmeasured quality tests.

\section{INSERT TABLE 7 HERE}

The results in Table 7 are somewhat mixed, but a number of findings emerge that are consistent with the main results. Looking first at Panel A, there are positive coefficients in all models for the foreign buyer and foreign seller variables, indicating a premium on both entry and exit for such investors. However, it is in the second sub-period when these coefficients are statistically significant. Coefficients for the other variables are less consistent. The price impact of buy side brokerage is no longer apparent, but the impact of sell side brokerage in achieving higher prices per square foot remains. The results in Panel B clearly reinforce the earlier conclusion that it is unmeasured quality that explains any premiums which exist. Only one of the 24 coefficients 
for asymmetry proxies is statistically significant compared to half of those for the unmeasured quality variables. In general, results for the matched samples are weakest, but it is here where the sub-period samples are at their smallest.

\section{Conclusion}

This study set out to test whether 'foreign' investors paid more when acquiring commercial real estate assets or received less when selling such assets once other determinants of price had been controlled for. This was done using samples of around 3,000 office deals in New York City over the period 2001-2015. By combining techniques that were used in previous studies of local and nonlocal investors, we found that price per square foot was higher, all else equal, when offices in New York City were acquired by foreign investors. However, we also found that when an office building was sold by a foreign investor, it sold at a premium. This suggests that it is unmeasured aspects of quality in the assets and not information asymmetry that drives differences in prices between foreign and domestic investors in this location. This finding contrasts with results from previous studies of local and nonlocal investors.

Our finding in relation to foreign investors makes sense given the prominence of the New York office market as destination for foreign investment and the scale of many international investors found in our sample. Moreover, it is consistent with the theoretical predictions of AlchianAllen (see Ling et al. 2013), who posit that distant investors confronted by higher transaction costs will invest in higher quality assets. Results from our probit models indicate that foreign purchases and sales are different in terms of observed attributes such as size, age and location. Our formal testing of the asymmetry and unmeasured quality hypotheses then indicate that 
unmeasured attributes are important as well, candidates for which could include tenant, lease, condition and amenity related factors. In contrast, we could not find support for information asymmetry effects either for the period as a whole or within sub-periods that reflected different market conditions.

Some other findings are also of interest. Our results in respect of experience, joint ventures and brokers led us to conduct similar tests in terms of whether asymmetries or unmeasured aspects of quality drove the price effects that we observed for these variables. For example, greater experience appears to correspond with higher prices. This makes sense on the sell side, but not the buy side of a deal unless quality is playing a role. Similarly, joint venture transactions are associated with higher prices when buying and selling, and yet they involve additional parties, which is likely to introduce greater experience to the transaction. When sellers use a broker, the price achieved is higher than when brokers are not involved and this effect is statistically significant. We did not observe a commensurately strong or significant result for buyer brokers, though. Our sums and differences model indicates that the presence of brokers might benefit investors when the counterparty is not similarly represented.

We deliberately chose to examine the New York office market on the grounds that New York is a global financial centre with high dollar volumes of foreign real estate investment. However, our findings raise the question as to whether the apparent absence of any information effects is a function of the unique features of this market or a reflection of large commercial real estate markets in general. Therefore, it would be interesting for future research to explore foreign investor activity and pricing in other cities, including less transparent markets. Future studies could seek to incorporate more control variables, perhaps by using more sophisticated spatial techniques and drawing upon further data sources. They could also explore alternative drivers 
for price premiums such as investor access to global capital markets or opportunities created by exchange rate movements that allow foreign investors to outbid local competitors.

\section{References}

Chegut, A. M., Eichholtz, P. M. A., \& Rodrigues, P. J. M. (2015). Spatial Dependence in International Office Markets. Journal of Real Estate Finance and Economics, 51, 317-350. doi:10.1007/s11146-014-9484-x.

Chinloy, P. W., Hardin, III., \& Wu, Z. (2013). Price, Place, People, and Local Experience. Journal of Real Estate Research, 35, 477-505.

Colwell, P. F., \& Munneke, H. J. (2006). Bargaining Strength and Property Class in Office Markets. Journal of Real Estate Finance and Economics, 33, 197-213. doi:10.1007/s11146006-9982-6.

Clauretie, T., \& Thistle, P. (2007). The Effect of Time-on-Market and Location on Search Costs and Anchoring: The Case of Single-Family Properties. Journal of Real Estate Finance and Economics, 35, 181-196. doi:10.1007/s11146-007-9034-х.

Crosby, N., Jackson, C., \& Orr, A. (2016). Refining the real estate pricing model. Journal of Property Research, 33, 332-358. doi: 10.1080/09599916.2016.1237539. 
Devaney, S., \& Scofield, D. (2013). Broker use and the cost of liquidity in commercial real estate investment. Journal of European Real Estate Research, 6, 279-302. doi: 10.1108/JERER-06-2013-0010.

Eichholtz, P., Holtermans, R. \& Yonder, E. (2016). The economic effects of owner distance and local property management in US office markets. Journal of Economic Geography, 16, 781-803. doi:10.1093/jeg/lbv018.

Harding, J. P., Rosenthal, S. S., \& Sirmans, C. F. (2003). Estimating bargaining power in the market for existing homes. The Review of Economics and Statistics, 85, 178-188. doi:10.1162/003465303762687794.

Ihlanfeldt, K., \& Mayock, T. (2012). Information, Search, and House Prices: Revisited. Journal of Real Estate Finance and Economics, 44, 90-115. doi:10.1007/s11146-010-9282-z.

Lambson, V. V., McQueen, G. R., \& Slade, B. A. (2004). Do Out of State Buyers Pay More for Real Estate? An Examination of Anchoring-Induced Bias and Search Costs. Real Estate Economics, 32, 85-126. doi:10.1111/j.1080-8620.2004.00085.x.

Levitt, S. D., \& Syverson, C. (2008). Market distortions when agents are better informed: The value of information in real estate transactions. The Review of Economics and Statistics, 90, 599-611. doi:10.1162/rest.90.4.599. 
Lieser, K. \& Groh, A. (2014). The Determinants of International Commercial Real Estate Investment. Journal of Real Estate Finance and Economics, 48, 611-659. doi:10.1007/s11146012-9401-0.

Ling, D. C., Naranjo, A., \& Petrova, M. (2013). Search Costs, Behavioral Biases, and Information Intermediary Effects. Paper presented at the 2013 Real Estate Research Institute conference. Retrieved from http://www.reri.org/research/article_pdf/ling_naranjo_petrova_apr2013.pdf.

Liu, Y., Gallimore, P., \& Wiley, J. A. (2015). Nonlocal office investors: anchored by their markets and impaired by their distance. The Journal of Real Estate Finance and Economics, 50, 129-149. doi:10.1007/s11146-013-9446-8.

Lizieri, C., J. Reinert \& Baum, A. (2011). Who Owns the City 2011: Change and Global Ownership of City of London Offices. University of Cambridge: Department of Land Economy.

Mauck, N. and Price, S. M. (2015). Determinants of Foreign Versus Domestic Real Estate Investment: Property Level Evidence from Listed Real Estate Investment Firms. Journal of Real Estate Finance and Economics, Forthcoming. doi:10.1007/s11146-015-9532-1.

McAllister, P., \& Nanda, A. (2015). Does Foreign Investment Affect US Office Real Estate Prices? The Journal of Portfolio Management, 41(6), 38-47. doi:10.3905/jpm.2015.41.6.038. 
McAllister, P., \& Nanda, A. (2016a). Does Real Estate Defy Gravity? An Analysis of Foreign

Real Estate Investment Flows. Review of International Economics, 24: 924-948. doi:10.1111/roie.12228.

McAllister, P. and Nanda, A. (2016b). Do Foreign Buyers Compress Office Real Estate Cap Rates? Journal of Real Estate Research, 38: 569-594.

Miller, N., M. Sklarz \& Ordway, N. (1988). Japanese purchases, exchange rates and speculation in residential real estate markets. Journal of Real Estate Research, 3(3), 39-49.

Neo, P., S.E. Ong \& Tu, Y. (2008). Buyer Exuberance and Price Premium. Urban Studies, 45, 331-345. doi:10.1177/0042098007085966.

Wiley, J. A. (2012). Buy high, sell low: Corporate investors in the office market. Real Estate Economics, 40, 843-860. doi:10.1111/j.1540-6229.2012.00341.x

Zhou, X., K. Gibler \& Zahirovic-Herbert, V. (2015). Asymmetric buyer information influence on price in a homogeneous housing market. Urban Studies, 52, 891-905. doi:10.1177/0042098014529464. 
Table 1: Sample sizes by number and value of deals, and average deal size

\begin{tabular}{|c|c|c|c|c|c|c|c|c|c|}
\hline & \multicolumn{3}{|c|}{ Total number of deals } & \multicolumn{3}{|c|}{ Total value of deals $\$ b n$. } & \multicolumn{3}{|c|}{ Average deal $\$ \mathrm{~m}$. } \\
\hline & Buyers & Sellers & All & Buyers & Sellers & All & Buyers & Sellers & All \\
\hline All transactions & 3,908 & 3,908 & 3,908 & 219.5 & 219.5 & 219.5 & 56.2 & 56.2 & 56.2 \\
\hline LLC involvement & 829 & 551 & 1,152 & 7.8 & 5.7 & 12.2 & 9.4 & 10.4 & 10.6 \\
\hline $\begin{array}{l}\text { Remaining } \\
\text { transactions }\end{array}$ & 3,079 & 3,357 & 2,756 & 211.7 & 213.8 & 207.3 & 68.8 & 63.7 & 75.2 \\
\hline $\begin{array}{l}\text { Remainder as \% } \\
\text { all }\end{array}$ & $78.8 \%$ & $85.9 \%$ & $70.5 \%$ & $96.5 \%$ & $97.4 \%$ & $94.4 \%$ & - & - & - \\
\hline Domestic investor & 2,837 & 3,104 & 2,319 & 157.9 & 167.5 & 119.1 & 55.7 & 53.9 & 51.4 \\
\hline Foreign investor & 242 & 253 & 437 & 53.8 & 46.3 & 88.2 & 222.3 & 183.1 & 201.8 \\
\hline $\begin{array}{l}\text { Foreign as \% } \\
\text { remainder }\end{array}$ & $7.9 \%$ & $7.5 \%$ & $15.9 \%$ & $25.4 \%$ & $21.7 \%$ & $42.5 \%$ & - & - & \\
\hline
\end{tabular}

Table 2: Means of the dependent and independent variables

\begin{tabular}{|c|c|c|c|c|c|c|}
\hline & \multicolumn{3}{|c|}{ Buyers } & \multicolumn{3}{|c|}{ Sellers } \\
\hline & Domestic & Foreign & All deals & Domestic & Foreign & All deals \\
\hline \multicolumn{7}{|l|}{ Continuous variables } \\
\hline Price $\$ \mathrm{~m}$ & 56 & 222 & 69 & 54 & 183 & 64 \\
\hline Price psf \$ & 385 & 583 & 400 & 376 & 544 & 389 \\
\hline Size 000 sf & 172 & 487 & 197 & 167 & 413 & 186 \\
\hline No of floors & 9 & 20 & 10 & 9 & 18 & 10 \\
\hline Age years & 36 & 26 & 35 & 36 & 28 & 35 \\
\hline \multicolumn{7}{|l|}{ Dummy variables } \\
\hline CBD & 0.55 & 0.79 & 0.57 & 0.54 & 0.72 & 0.55 \\
\hline Partial interest & 0.05 & 0.21 & 0.07 & 0.06 & 0.14 & 0.06 \\
\hline Condo interest & 0.10 & 0.12 & 0.10 & 0.10 & 0.11 & 0.10 \\
\hline Bought to renovate & 0.10 & 0.12 & 0.10 & 0.09 & 0.13 & 0.10 \\
\hline Joint venture & 0.12 & 0.31 & 0.13 & 0.12 & 0.36 & 0.14 \\
\hline Broker used & 0.12 & 0.14 & 0.12 & 0.55 & 0.70 & 0.56 \\
\hline Experienced & 0.44 & 0.38 & 0.43 & 0.40 & 0.45 & 0.40 \\
\hline \multicolumn{7}{|c|}{ Investor type dummies } \\
\hline Equity fund & 0.09 & 0.07 & 0.09 & 0.08 & 0.09 & 0.09 \\
\hline Institution & 0.08 & 0.38 & 0.10 & 0.12 & 0.42 & 0.14 \\
\hline Private & 0.62 & 0.29 & 0.60 & 0.61 & 0.28 & 0.58 \\
\hline Public & 0.05 & 0.13 & 0.06 & 0.05 & 0.06 & 0.05 \\
\hline User/other & 0.16 & 0.13 & 0.16 & 0.14 & 0.14 & 0.14 \\
\hline
\end{tabular}


Table 3: Factors influencing likelihood that asset will be traded by foreign investors

\begin{tabular}{lrrr}
\hline & Foreign buyer & Foreign seller & $\begin{array}{c}\text { Foreign buyer } \\
\text { or seller }\end{array}$ \\
\hline Constant & $-4.61^{* * *}$ & $-4.94 * * *$ & $-4.86 * * *$ \\
Log floorspace & $0.22^{* * *}$ & $0.27^{* * *}$ & $0.29 * * *$ \\
No of floors & 0.00 & 0.01 & 0.01 \\
Age & $-0.01 * *$ & 0.00 & $-0.01 *$ \\
Age squared & $0.00 *$ & 0.00 & 0.00 \\
CBD location & -0.03 & -0.11 & -0.11 \\
Part interest & 0.15 & $-0.29 * *$ & 0.03 \\
Condo interest & $0.22 *$ & $0.23 *$ & $0.29 * *$ \\
To renovate & -0.15 & -0.04 & -0.09 \\
Manhattan & $0.55 * * *$ & $0.45 * * *$ & $0.54 * * *$ \\
Year dummies & YES & YES & YES \\
\hline Observations & 2,701 & 2,938 & 2,427 \\
Pseudo r-sq. & $15.3 \%$ & $12.7 \%$ & $15.4 \%$ \\
LR $\chi 2$ & 220.2 & 211.0 & 320.6 \\
Probability $>\chi 2$ & 0 & 0 & 0 \\
\hline
\end{tabular}

Notes: $* * * * *$ and $*$ denote $1 \%, 5 \%$ and $10 \%$ significance levels, respectively. The dependent variable is a $0 / 1$ dummy that (depending which model) indicates whether the buyer, the seller or either party was a foreign investor. The year dummies identify transactions in each year for the period 2001-15. 
Table 4: Factors affecting office pricing - asset, location and purchaser variables

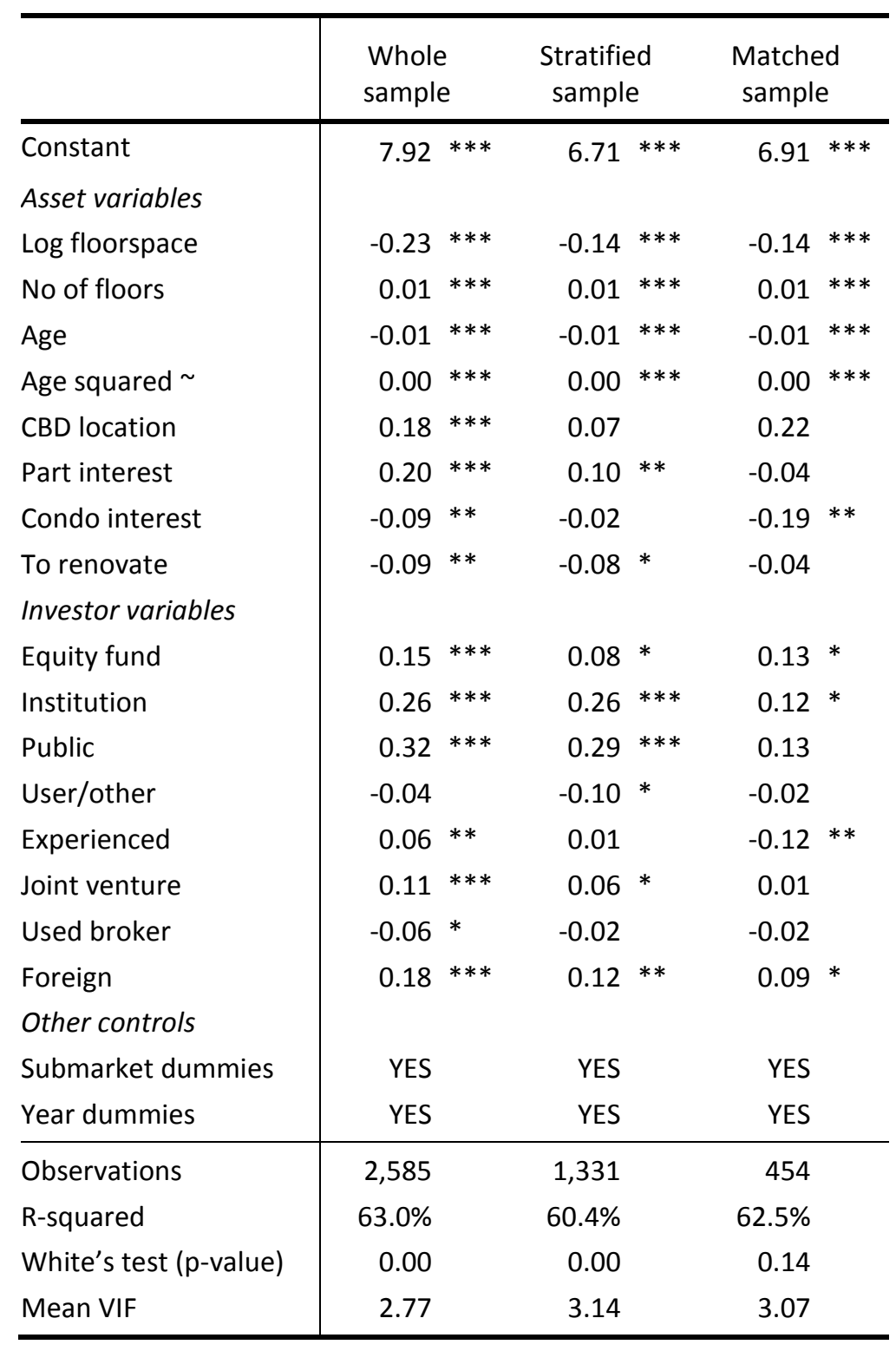

Notes: $* * *, * *$ and $*$ denote $1 \%, 5 \%$ and $10 \%$ significance levels, respectively. Heteroscedasticity consistent standard errors are used. The dependent variable is the log of price per square foot. Year dummies identify transactions in each year for the period 2001-15 and control for general market movements in prices.

$\sim$ The coefficient on age squared is positive and non-zero at the fourth decimal place. 
Table 5: Factors affecting office pricing - asset, location and seller variables

\begin{tabular}{|c|c|c|c|c|c|c|}
\hline \multirow[b]{2}{*}{ Constant } & \multicolumn{2}{|c|}{$\begin{array}{l}\text { Whole } \\
\text { sample }\end{array}$} & \multicolumn{2}{|c|}{$\begin{array}{l}\text { Stratified } \\
\text { sample }\end{array}$} & \multicolumn{2}{|c|}{$\begin{array}{l}\text { Matched } \\
\text { sample }\end{array}$} \\
\hline & 8.11 & $* * *$ & 6.35 & $* * *$ & 7.39 & $* * *$ \\
\hline Log floorspace & -0.24 & $* * *$ & -0.12 & $* * *$ & -0.21 & $* * *$ \\
\hline No of floors & 0.01 & $* * *$ & 0.01 & $* * *$ & 0.02 & $* * *$ \\
\hline Age & -0.01 & $* * *$ & -0.01 & $* * *$ & -0.01 & $* * *$ \\
\hline Age squared & 0.00 & $* * *$ & 0.00 & $* * *$ & 0.00 & $* *$ \\
\hline CBD location & 0.08 & & 0.15 & & 0.07 & \\
\hline Part interest & 0.26 & $* * *$ & 0.16 & $* * *$ & 0.21 & $* *$ \\
\hline Condo interest & -0.11 & $* * *$ & 0.04 & & -0.27 & $* * *$ \\
\hline $\begin{array}{l}\text { To renovate } \\
\text { Investor variables }\end{array}$ & -0.05 & & -0.06 & & -0.26 & $* * *$ \\
\hline Equity fund & 0.06 & & 0.06 & & -0.02 & \\
\hline Institution & -0.05 & & 0.01 & & -0.15 & $*$ \\
\hline Public & 0.14 & $* * *$ & 0.13 & $* *$ & 0.11 & \\
\hline User/other & -0.02 & & 0.06 & & 0.00 & \\
\hline Experienced & 0.09 & $* * *$ & 0.09 & $* *$ & 0.10 & \\
\hline Joint venture & 0.17 & $* * *$ & 0.13 & $* * *$ & 0.05 & \\
\hline Used broker & 0.05 & $* *$ & 0.12 & $* * *$ & 0.21 & $* * *$ \\
\hline Foreign & 0.14 & $* * *$ & 0.09 & $*$ & 0.17 & $* *$ \\
\hline Other controls & & & & & & \\
\hline Submarket dummies & YES & & YES & & YES & \\
\hline Year dummies & YES & & YES & & YES & \\
\hline Observations & 2,655 & & 1,419 & & 443 & \\
\hline R-squared & $63.2 \%$ & & $61.0 \%$ & & $62.6 \%$ & \\
\hline White's test ( $p$-value) & 0.00 & & 0.00 & & 0.22 & \\
\hline Mean VIF & 2.80 & & 2.72 & & 3.40 & \\
\hline
\end{tabular}

Notes: $* * *, * *$ and $*$ denote $1 \%, 5 \%$ and $10 \%$ significance levels, respectively. Heteroscedasticity consistent standard errors are used. The dependent variable is the log of price per square foot. Year dummies identify transactions in each year for the period 2001-15 and control for general market movements in prices.

$\sim$ The coefficient on age squared is positive and non-zero at the fourth decimal place. 
Table 6: Results for models that test the effect of purchaser and seller attributes on pricing

\begin{tabular}{|c|c|c|c|c|c|c|}
\hline \multirow[b]{2}{*}{ Constant } & \multicolumn{2}{|c|}{$\begin{array}{l}\text { Whole } \\
\text { sample }\end{array}$} & \multicolumn{2}{|c|}{$\begin{array}{l}\text { Stratified } \\
\text { sample }\end{array}$} & \multicolumn{2}{|c|}{$\begin{array}{l}\text { Matched } \\
\text { sample }\end{array}$} \\
\hline & 8.03 & $* * *$ & 6.44 & $* * *$ & 7.07 & $* * *$ \\
\hline \multicolumn{7}{|l|}{ Asset variables } \\
\hline Log floorspace & -0.24 & $* * *$ & -0.14 & $* * *$ & -0.17 & $* * *$ \\
\hline No of floors & 0.01 & $* * *$ & 0.01 & $* * *$ & 0.01 & $* * *$ \\
\hline Age & -0.01 & $* * *$ & -0.01 & $* * *$ & -0.01 & $* * *$ \\
\hline Age squared & 0.00 & $* * *$ & 0.00 & $* * *$ & 0.00 & $* * *$ \\
\hline CBD location & 0.15 & $* *$ & 0.15 & & 0.15 & \\
\hline Part interest & 0.17 & $* * *$ & 0.11 & $* *$ & 0.18 & $* * *$ \\
\hline Condo interest & -0.06 & & 0.07 & & -0.04 & \\
\hline To renovate & -0.08 & $* *$ & -0.06 & & -0.07 & \\
\hline \multicolumn{7}{|l|}{ Investor variables } \\
\hline Equity fund buyer & 0.12 & $* * *$ & 0.04 & & -0.04 & \\
\hline Institution buyer & 0.24 & $* * *$ & 0.22 & $* * *$ & 0.16 & $* * *$ \\
\hline Public buyer & 0.31 & $* * *$ & 0.25 & $* * *$ & 0.18 & $* * *$ \\
\hline User/other buyer & -0.05 & & -0.16 & $* * *$ & 0.00 & \\
\hline Equity fund seller & 0.06 & & 0.06 & & -0.01 & \\
\hline Institution seller & -0.01 & & 0.02 & & 0.05 & \\
\hline Public seller & 0.11 & $* *$ & 0.15 & $* *$ & 0.09 & \\
\hline User/other seller & -0.02 & & 0.10 & & 0.18 & $* *$ \\
\hline \multicolumn{7}{|l|}{ Asymmetry tests } \\
\hline Exp. buyer - Exp. seller & 0.00 & & -0.01 & & -0.02 & \\
\hline JV buyer - JV seller & -0.02 & & -0.04 & & 0.05 & \\
\hline Broker buyer - Broker seller & -0.06 & $* *$ & -0.10 & $* * *$ & -0.03 & \\
\hline Foreign buyer - Foreign seller & 0.03 & & 0.03 & & 0.04 & \\
\hline \multicolumn{7}{|l|}{ Unmeasured quality tests } \\
\hline Exp. buyer + Exp. seller & 0.06 & $* * *$ & 0.04 & & 0.07 & $*$ \\
\hline JV buyer + JV seller & 0.11 & $* * *$ & 0.07 & $* * *$ & 0.09 & $* *$ \\
\hline Broker buyer + Broker seller & -0.02 & & 0.02 & & 0.01 & \\
\hline Foreign buyer + Foreign seller & 0.14 & $* * *$ & 0.10 & $* * *$ & 0.11 & $* * *$ \\
\hline \multicolumn{7}{|l|}{ Other controls } \\
\hline Submarket and year dummies & YES & & YES & & YES & \\
\hline Observations & 2,162 & & 1,170 & & 780 & \\
\hline R-squared & $64.3 \%$ & & $62.4 \%$ & & $60.2 \%$ & \\
\hline White's test (p-value) & 0.00 & & 0.07 & & 0.00 & \\
\hline Mean VIF & 2.56 & & 2.60 & & 2.63 & \\
\hline
\end{tabular}

Notes: ${ }^{* * *},{ }^{* *}$ and $*$ denote $1 \%, 5 \%$ and $10 \%$ significance levels, respectively. Heteroscedasticity consistent standard errors are used. The dependent variable is the log of price per square foot. Year dummies identify transactions in each year for the period 2001-15 and control for general market movements in prices. The coefficient on age squared is positive and nonzero at the fourth decimal place. 
Table 7: Sub-period results for foreign investor and selected other variables

\begin{tabular}{|c|c|c|c|c|c|c|c|c|}
\hline & \multicolumn{3}{|c|}{ Sub-period 1: 2001-2007 } & \multicolumn{5}{|c|}{ Sub-period 2: 2008-2015 } \\
\hline \multicolumn{9}{|c|}{ Panel A: Coefficients on investor dummy variables } \\
\hline & Whole & Stratified & Matched & Whole & & Stratified & Match & hed \\
\hline \multicolumn{9}{|l|}{ Models with buyer variables } \\
\hline Experienced buyer & 0.05 & 0.02 & -0.03 & $0.07 *$ & & 0.07 & 0.15 & $*$ \\
\hline Joint venture buyer & 0.07 & 0.03 & 0.07 & $0.12 *$ & $* * *$ & 0.08 & -0.02 & \\
\hline Used broker & -0.02 & 0.02 & -0.08 & -0.06 & & -0.04 & 0.17 & $* *$ \\
\hline Foreign buyer & 0.10 & 0.09 & 0.09 & $0.21 *$ & $* * *$ & $0.14 * *$ & 0.37 & $* * *$ \\
\hline \multicolumn{9}{|l|}{ Models with seller variables } \\
\hline Experienced seller & $0.10 * * *$ & $0.13 * * *$ & -0.01 & $0.08 *$ & $* *$ & $0.12 * *$ & 0.24 & $* *$ \\
\hline Joint venture seller & $0.14 * * *$ & $0.09 *$ & 0.14 & $0.14 *$ & $* * *$ & 0.09 & -0.09 & \\
\hline Used broker & 0.03 & $0.09 *$ & 0.07 & 0.05 & & $0.16 * * *$ & 0.21 & $*$ \\
\hline Foreign seller & $0.10 *$ & 0.07 & 0.10 & $0.17 *$ & $* *$ & $0.17 *$ & 0.19 & $*$ \\
\hline \multicolumn{9}{|c|}{ Panel B: Coefficients for tests in combined models } \\
\hline & Whole & Stratified & Matched & Whole & & Stratified & Matche & hed \\
\hline \multicolumn{9}{|l|}{ Asymmetry tests } \\
\hline Exp. buyer - Exp. seller & -0.03 & -0.04 & 0.01 & 0.00 & & -0.01 & 0.02 & \\
\hline JV buyer - JV seller & -0.04 & -0.04 & 0.00 & -0.01 & & -0.03 & 0.13 & $* *$ \\
\hline Broker buyer - Broker seller & -0.04 & -0.06 & 0.00 & -0.05 & & -0.07 & -0.02 & \\
\hline \multicolumn{8}{|l|}{ Unmeasured quality tests } & \\
\hline Exp. buyer + Exp. seller & $0.06 * *$ & $0.09 * *$ & 0.07 & $0.06 *$ & $* *$ & 0.02 & -0.03 & \\
\hline JV buyer + JV seller & $0.08 * * *$ & 0.04 & 0.03 & $0.11 *$ & $* * *$ & $0.07 *$ & 0.02 & \\
\hline Broker buyer + Broker seller & 0.00 & 0.02 & $0.12 *$ & -0.02 & & 0.01 & 0.06 & \\
\hline Foreign buyer + Foreign seller & $0.09 * *$ & $0.09 * *$ & $0.08 *$ & $0.17 *$ & $* * *$ & $0.10 *$ & 0.07 & \\
\hline
\end{tabular}

Notes: $* * *, * *$ and $*$ denote $1 \%, 5 \%$ and $10 \%$ significance levels, respectively. Heteroscedasticity consistent standard errors are used. The dependent variable is the log of price per square foot in each case. Year dummies identify transactions in each year for the sub-period concerned. Submarket and other controls are also included in all cases. 